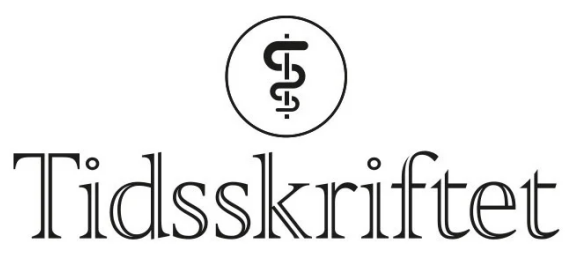

DEN NORSKE LEGEFORENING

\title{
Når blir mutant til variant?
}

SPRÅKSPALTEN

ANNE SPURKLAND

anne.spurkland@medisin.uio.no

Anne Spurkland er spesialist i immunologi og transfusjonsmedisin og professor ved Universitetet i Oslo. Hun har utgitt to populærvitenskapelige bøker om immunsystemet og har vært mye brukt av media som fagperson under covid-19-pandemien.

\section{Mange begreper som brukes om virus, er dårlig definert. Endringer i SARS-CoV-2-viruset, som forårsaker covid-19, har gitt oss innsikt i hvordan et virus gjennom mutasjoner tilpasser seg vertsbefolkningen i løpet av en pandemi.}

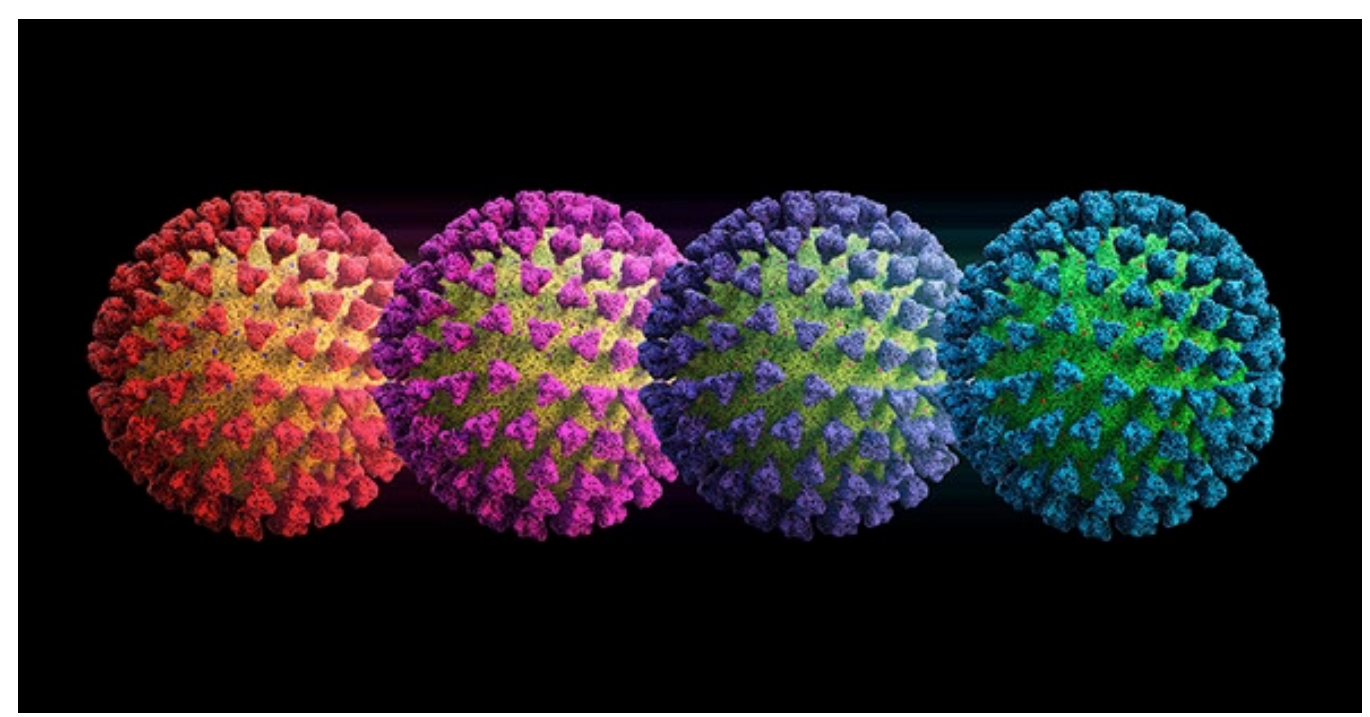

Illustrasjon: Science Photo Library / NTB

Over 235 millioner mennesker har vært smittet med SARS-CoV-2-viruset og flere enn 4,8 millioner er døde så langt i covid-19-pandemien. Det opprinnelige SARS-CoV-2-viruset kom fra Kina. Underveis i pandemien har viruset mutert, og vi har fătt nye varianter som sprer seg lettere og som kanskje også gir mer alvorlig sykdom.

Spredningen av SARS-CoV-2 har gått i bølger, slik man også har sett i tidligere pandemier. Forskjellen denne gangen er at vi for første gang har kunnet studere spredningen av viruset i detalj, via virusets eget arvestoff. Dette har gitt oss innsikt i hvordan et virus endrer seg og 
tilpasser seg vertsbefolkningen i løpet av en pandemi. Det gjør det aktuelt å se nærmere på begrepene som brukes for å snakke om viruset. Hva er en mutant? Og hva er en variant? Dette har med endringer i arvestoffet å gjøre.

\section{Virusmutant}

Arvestoffet til SARS-CoV-2 er RNA og inneholder rundt 30 ooo nukleotider eller baser, dvs. basene adenin, uracil, cytosin og guanin (forkortet $A, U, C \operatorname{og} G$ ), som koder for omtrent 30 proteiner. Det er relativt stort til å være virus. Den første publiserte sekvensen av SARSCoV-2-arvestoffet er referansesekvensen.

Når et virus har infisert en celle og skal gi opphav til nye virus, blir arvestoffet kopiert ved hjelp av baseparing. Det nye virus-arvestoffet blir pakket inn i nye viruspartikler som slippes ut av den infiserte cellen. Selv om baseparingen foregår nøyaktig, skjer det likevel av og til at en feil base inkluderes i den nye kopien av arvestoffet. Dette kalles en mutasjon. Virus med en nylig oppstått mutasjon i arvestoffet, kalles en mutant. Noen virus, som for eksempel SARS-CoV-2, har evne til å oppdage og korrigere feil i kopieringen av arvestoffet idet de oppstår. De muterer derfor relativt sjelden. Andre virus, som hiv, muterer ganske hyppig.

\section{"Både for hiv og SARS-CoV-2 har man kunnet vise at $i$ én enkelt person med aktivt replikerende virus, finnes det et stort antall ulike virusmutanter»}

Både for hiv og SARS-CoV-2 har man kunnet vise at i én enkelt person med aktivt replikerende virus, finnes det et stort antall ulike virusmutanter $(\underline{1}, \underline{2})$. Enhver smittet person vil dermed kunne spre videre muterte viruspartikler som ikke er helt identisk med de vedkommende selv ble smittet med.

I løpet av pandemien er det registrert et svært stort antall SARS-CoV-2-virus med en eller flere nukleotider som er forskjellig fra det «opprinnelige» SARS-CoV-2-viruset. Disse endringene i virusarvestoffet har gitt grunnlag for å følge spredningen av viruset over tid (3).

\section{Nøytrale, skadelige eller gunstige mutasjoner}

Ordet mutasjon gir gjerne negative assosiasjoner. En mutant er et avvik fra det forventede, og ordet brukes gjerne i populærkulturen om et individ med et lite tiltalende utseende eller med uhyggelige eller overdrevne egenskaper. I virkeligheten er mutasjoner tilfeldige. Konsekvensen av en mutasjon for et virus, er avhengig av miljøet der mutasjonen har skjedd. Det som avgjør om en mutasjon er nøytral, skadelig eller gunstig, er om endringen $\emptyset$ ker virusets evne og mulighet til å spre seg videre til nye verter.

Når vi nå i snart to år har holdt avstand til hverandre, vil mutasjoner som øker virusets smittsomhet, få en fordel. Mutasjoner som gjør at viruset lettere binder seg til reseptorer på målcellene, eller som gjør at en smittet person sender fra seg flere viruspartikler, vil få en fordel. Når viruset ikke bare skal overkomme økt avstand mellom folk, men også klare å spre seg i nærvær av et pågående immunforsvar, vil mutasjoner som endrer de delene av viruset som immunforsvaret reagerer på, gi viruset en fordel.

\section{Fra mutasjon til variasjon: frekvens}


Det er ingen prinsipiell forskjell mellom genetisk variasjon og mutasjon. Begge deler er en varig endring i arvestoffet som kan overføres til cellens eller organismens etterkommere. Om endringen fører til at organismen får en ny egenskap eller ikke, er irrelevant.

Forskjellen mellom genetisk variasjon og mutasjon er hvor hyppig endringen forekommer i befolkningen.

I populasjonsgenetikken skiller man mellom polymorfi, som er et annet ord for variasjon, og mutasjon. Grensen for når en mutasjon går over til å bli en polymorfi, bestemmes av hyppigheten i befolkningen. En tommelfingerregel er at når en mutasjon finnes blant mer enn $1 \%$ av befolkningens gener, kalles det en polymorfisme. Innen virologien har man ikke et liknende skille. Likevel, i praksis blir et virus kalt en mutant hvis den er sjelden, og en variant hvis den er mer vanlig. Alle de muterte virusene vi nå hører om, er etablert som varianter, siden de er blitt så hyppige.

Først i november 2020 kom begrepet virusvarianter i søkelyset for alvor. Da hadde pandemien noen steder i verden kommet så langt at mange var blitt helt eller delvis immune. Begrepene variant of interest (forkortet VOI) og variant of concern (forkortet VOC) betegner virus med én eller flere mutasjoner som kunne gi grunn til bekymring. Ville vaksine eller gjennomgått infeksjon beskytte godt nok mot ny infeksjon med slike bekymringsfulle varianter?

\section{Navnsetting av virusvarianter}

De utallige ulike virusmutantene og variantene som har blitt påvist siden pandemien startet, har gitt utfordringer i forhold til hvordan de skal omtales. I media har virusvarianter med antatt endret funksjon på grunn av mutasjoner, særlig i piggproteinet (også kjent som spike-proteinet), blitt omtalt i henhold til hvor de først ble oppdaget: den britiske varianten, den indiske varianten osv. Den mest brukte vitenskapelige nomenklaturen har vært en tallserie, som har vært vanskelig å huske: B.1.1.7 er den britiske varianten, B.1.167.1 er den indiske varianten osv.

«Det er ingen prinsipiell forskjell mellom genetisk variasjon og mutasjon»

I slutten av mai 2021 besluttet Verdens helseorganisasjon å omtale de ulike variantene med greske bokstaver, slik at britiske B.1.1.7 ble alfa; B.1.351, som først ble oppdaget i Sør-Afrika, ble kalt beta; P1, som først ble oppdaget i Brasil, ble gamma; mens den indiske B.1.167.1 ble delta.

\section{Virusbegrep i endring}

Mange begreper som brukes om virus, er dårlig definert, og det finnes heller ikke noen «virusbibel» med fasitsvaret (4). Tidligere ble mutasjoner i virus først erkjent når endringen fikk funksjonell betydning, enten i laboratoriet eller klinisk. Under covid-19-pandemien har vi kunnet følge utviklingen av virusvarianter nærmest mutasjon for mutasjon. Det store antallet variasjoner og mutasjoner er kanskje frustrerende og forvirrende, men denne detaljerte informasjonen gir samtidig et unikt innblikk i hvordan virusets egenskaper utvikles som konsekvens av både vår atferd og vårt immunforsvar (5).

\section{LITTERATUR}

1. McCormick KD, Jacobs JL, Mellors JW. The emerging plasticity of SARS-CoV-2. Science 2021; 371: 13068. [PubMed][CrossRef] 
2. Avila-Rios S, Carlson JM, John M et al. Clinical and evolutionary consequences of HIV adaptation to HLA: implications for vaccine and cure. Curr Opin HIV AIDS 2019; 14: 194-204. [PubMed][CrossRef]

3. World Health Organization. SARS-CoV-2 genomic sequencing for public health goals: Interim guidance, 8 January 2021. https://www.who.int/publications/i/item/WHO-2019-nCoVgenomic_sequencing-2021.1 Lest 31.8.2021.

4. Racaniello V. Understanding virus isolates, variants, and strains. Virology Blog. https://www.virology.ws/2021/02/25/understanding-virus-isolates-variants-strains-and-more/ Lest 31.8.2021.

5. Velázquez FR. Coronavirus mutations and variants: What does it mean. Spokane Regional Health District. https://srhd.org/news/2021/coronavirus-mutations-and-variants-what-does-it-mean Lest 31.8.2021.

Publisert: 25. oktober 2021. Tidsskr Nor Legeforen. DOI: 10.4045/tidsskr.21.0492

(C) Tidsskrift for Den norske legeforening 2023. Lastet ned fra tidsskriftet.no 26. april 2023. 